\title{
Factors Influencing Filament Length of Methanospirillum hungatii
}

\author{
By G. B. PATEL, L. A. ROTH* AND G. D. SPROTT \\ Division of Biological Sciences, National Research Council of Canada, \\ Ottawa, Ontario K1A OR6, Canada
}

(Received 24 January 1979)

\begin{abstract}
Cultivation of Methanospirillum hungatii $\mathrm{GP} 1$ at $35^{\circ} \mathrm{C}$ in low $\mathrm{PO}_{4}{ }^{3-}(3.0 \mathrm{~mm})$ medium resulted in growth as motile curved rods $(6$ to $8 \times 0.5 \mu \mathrm{m})$. However, predominantly long filaments averaging 70 to $300 \mu \mathrm{m}$ were observed in the presence of high concentrations of $\mathrm{PO}_{4}{ }^{3-}(43.7 \mathrm{~mm})$ or $\mathrm{Na}^{+}(225 \mathrm{~mm})$ or after incubation at $25^{\circ} \mathrm{C}$ in low $\mathrm{PO}_{4}{ }^{3-}$ medium. These conditions also resulted in decreased growth rates. Tests with cell-free extracts of long and short form filaments indicated that long filament formation is probably related to a deficiency in heat-labile factor(s) required for cell separation.
\end{abstract}

\section{INTRODUCTION}

The cell morphology of many micro-organisms can be manipulated by the control of growth conditions such as nutrient supply (Webb, 1951) and incubation temperature (Gounot, 1976). Some of the morphological changes have been attributed to failure of septation (Ferroni \& Inniss, 1974) and to decreased activity of cell separation enzymes (Lominski et al., 1958). Morphological changes have been studied only superficially in the obligately anaerobic, methanogenic bacteria. Filament formation and coiling occur in Methanobacterium thermoautotrophicum (Zeikus \& Wolfe, 1973); chaining in Methanobacterium formicicum (Mylroie \& Hungate, 1954), Methanobacterium ruminantium (Smith \& Hungate, 1958), Methanobacterium arbophilicum (Zeikus \& Henning, 1975); and filament formation in Methanospirillum hungatii JF1 (Ferry et al., 1974). In most cases the above morphological types were neither predominant nor selectively enhanced over other types present, with the exceptions of temperature-controlled morphology changes in M. thermoautotrophicum (Zeikus \& Wolfe, 1973) and nutrient-mediated morphology changes of Methanobacterium strain AZ (Zehnder \& Wuhrmann, 1977). This paper reports on the selective cultivation of $M$. hungatii as predominantly long filaments and on some of the factors responsible for this morphological change.

\section{METHODS}

Media. The composition of sodium carbonate-buffered synthetic acetate broth (SA, 3.0 mM-PO ${ }_{4}{ }^{3-}$ ) used

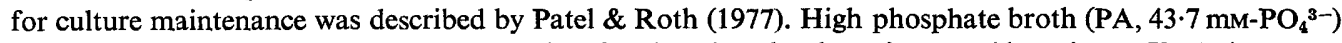
was of the same composition as $\mathrm{SA}$, except that the phosphate level was increased by using $\mathrm{K}_{2} \mathrm{HPO}_{4} / \mathrm{KH}_{2} \mathrm{PO}_{4}$ buffer ( $0.05 \mathrm{M}, \mathrm{pH} 7 \cdot 0)$ to dissolve the ingredients. All media were pre-reduced and, unless stated otherwise, $10 \mathrm{ml}$ samples were dispensed under $\mathrm{H}_{2} / \mathrm{CO}_{2}(4: 1, \mathrm{v} / \mathrm{v})$ into $160 \mathrm{ml}$ serum vials fitted with butyl rubber stoppers. The $\mathrm{pH}$ values of the media after autoclaving $(103 \mathrm{kPa}$ for $15 \mathrm{~min})$ were 6.8 to 7.0 at $25^{\circ} \mathrm{C}$.

Culture maintenance and inocula preparation. Stock cultures of Methanospirillum hungatii GP1 (Patel et al., 1976; National Research Council of Canada Culture Collection no. 2214) were maintained by weekly transfers into SA broth. Cultures for inoculum or cell extract preparation were cultivated for 1 week at $35^{\circ} \mathrm{C}$ under $\mathrm{H}_{2} / \mathrm{CO}_{2}(4: 1, \mathrm{v} / \mathrm{v})$ in SA broth if short filaments were desired and in PA broth if long filaments were needed. In most instances the inoculum was 1 to $2 \%(\mathrm{v} / \mathrm{v})$ to give an initial count of about $5 \times 10^{6}$ filaments $\mathrm{ml}^{-1}$ in the test medium.

* Present address: Alberta Agriculture, Food Laboratory, O.S. Longman Building, Edmonton, Alberta T6H 4P2, Canada. 


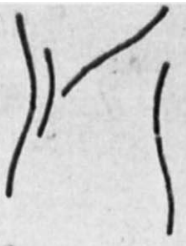

o

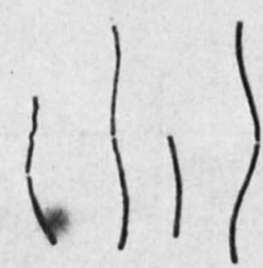

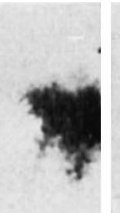

(b)

$(c)$

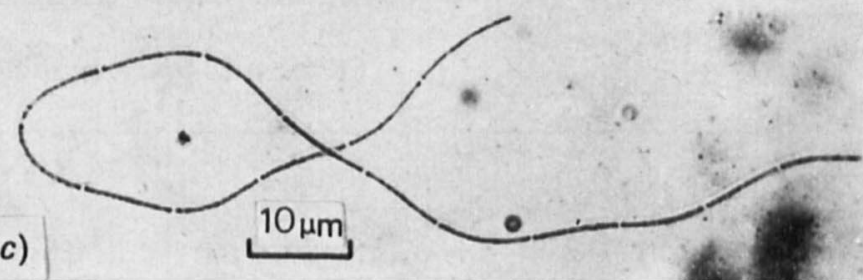

Fig. 1. Methanospirillum hungatii GP1 filaments stained with Victoria blue to visualize the cell spacers: (a) grown in SA broth; (b) grown in PA broth; $(c)$ grown in PA broth but treated with $0.75 \mathrm{M}$-sucrose before staining.

Experimental analyses. Growth was estimated turbidimetrically $\left(A_{660}\right)$; these estimates correlated well with cell protein determinations (Lowry et al., 1951). Methane in the culture head-space was assayed as described by Patel \& Roth (1977). Cell spacers in the filaments (equivalent to septa in Gram-positive bacteria) were visualized by bright-field microscopy, after fixing washed filaments (Tris/ $\mathrm{HCl}$ buffer, $0.01 \mathrm{M}, \mathrm{pH} \mathrm{8.0)}$ with Bouin's fluid by diffusion through agar blocks and staining (10 to $15 \mathrm{~s}$ ) with $0.05 \%$ Victoria blue (Robinow \& Murray, 1953). In some experiments the cells were plasmolysed by incubation in $0.75 \mathrm{M}$-sucrose for $30 \mathrm{~min}$ prior to fixation.

Measurement of filament length. Filament length was measured with an ocular micrometer using phasecontrast optics. However, this method was not suitable for the accurate measurement of filaments in excess of $100 \mu \mathrm{m}$ or for those not lying in a straight path. This problem was overcome by measuring filaments ranging in length from 8 to $500 \mu \mathrm{m}$ by careful alignment with the ocular micrometer and also counting the number of wave crests and troughs in each filament. (The latter is easily accomplished using phase contrast optics, since most of the filaments appear in a regular wave-like arrangement.) The average distance between the highest point of a crest and the lowest point of an adjacent trough was found to be $8.75 \pm 0.13 \mu \mathrm{m}$ (968 measurements in 90 filaments). Consequently, the number of crests and troughs in a filament were counted and multiplied by 8.75 to estimate filament length.

Cell extract preparation. Filaments were harvested by centrifuging $(23000 \mathrm{~g}, 30 \mathrm{~min})$, washed once in Tris/ $\mathbf{H C l}$ buffer and disrupted ultrasonically for $3 \mathrm{~min}$ in $30 \mathrm{~s}$ bursts ( $95 \%$ breakage). The extracts were stored under $\mathrm{H}_{2} / \mathrm{CO}_{2}(4: 1, v / v)$ and used the same day

Electron microscopy. Thin sections of $M$. hungatii were prepared and examined as described by Colvin \& Leppard (1977).

\section{RESULTS AND DISCUSSION}

Methanospirillum hungatii GP1 grew in SA broth as single motile rods (6 to $8 \times 0.5 \mu \mathrm{m})$ and filaments (16 to $18 \times 0.5 \mu \mathrm{m}$ ) (Fig. $1 a$ ). Occasional filaments up to $100 \mu \mathrm{m}$ were also seen. Electron microscopic examination of ultra-thin sections indicated that each filament was composed of individual cells enclosed in a sheath-like structure and separated by discrete, unique partitions, called cell spacers. In these aspects the ultrastructure of $M$. hungatii strain GP1 is similar to that of strain 3P3 described by Zeikus \& Bowen (1975). The cell spacers are not usually evident by phase-contrast or bright-field microscopy without special staining procedures.

In contrast to growth as short filaments in SA broth, $M$. hungatii grew primarily as long filaments (at least $100 \mu \mathrm{m}$ ) when cultured in PA broth. Victoria blue staining of the long filaments indicated that the cell spacers were about $9 \mu \mathrm{m}$ apart, as observed for the short filaments grown in SA broth (Fig. 1). The ion which induced the growth of long filaments 
Table 1. Mean filament lengths of $M$. hungatii GP1 in different media

Supplements [short-filament extract (SFE), long-filament extract (LFE) or 'supernatant'] were added to the growth medium $(10 \mathrm{ml}$ in $160 \mathrm{ml}$ serum vials) before inoculation with short filaments grown in SA broth. Heated extracts were maintained at $85^{\circ} \mathrm{C}$ for $5 \mathrm{~min}$. 'Supernatant' was $0.2 \mathrm{ml}$ of SA growth medium from which short filaments had been harvested. $\mathrm{H}_{2}$ and $\mathrm{CO}_{2}$ were replenished daily. Filaments were measured after $7 \mathrm{~d}$ incubation at $35^{\circ} \mathrm{C}$; the results show the mean length \pm standard error, and (in parentheses) the number of filaments counted.

$\begin{array}{cc}\begin{array}{c}\text { Growth } \\ \text { medium }\end{array} & \begin{array}{c}\text { Supplement } \\ {[\mu \text { g protein (ml broth) }}\end{array} \\ \text { SA } & \text { None } \\ \text { PA } & \text { None } \\ \text { PA } & \text { SFE (50) } \\ \text { PA } & \text { SFE (200) } \\ \text { PA } & \text { Heated SFE (200) } \\ \text { PA } & \text { LFE (180) } \\ \text { PA } & \text { Heated LFE (180) } \\ \text { PA } & \text { 'Supernatant' }\end{array}$

$\begin{array}{cc}\begin{array}{c}\text { Filament length } \\ (\mu \mathrm{m})\end{array} & \begin{array}{c}\text { Methane } \\ \text { accumulated } \\ (\mathrm{mmol})\end{array} \\ 16 \cdot 10 \pm 0 \cdot 80(60) & 1 \cdot 40 \\ 218 \pm 15(60) & 1 \cdot 41 \\ 177 \pm 22(20) & 1 \cdot 13 \\ 88 \cdot 6 \pm 2 \cdot 1(80) & 1 \cdot 07 \\ 150 \cdot 0 \pm 9 \cdot 1(60) & 1 \cdot 14 \\ 222 \pm 19(40) & 1 \cdot 33 \\ 214 \pm 22(40) & 1 \cdot 00 \\ 220 \pm 29(20) & 1 \cdot 00\end{array}$

was $\mathrm{PO}_{4}{ }^{3-}$ rather than $\mathrm{K}^{+}$, since growth in SA broth supplemented with up to $100 \mathrm{mM}-\mathrm{KCl}$ yielded predominantly short filaments. Electron microscopic examination of ultra-thin sections indicated no obvious structural differences between the cell walls of long and short filaments.

Experiments were conducted to determine if filament length correlated with the growth rate of the culture. Biomass doubling times, determined turbidimetrically in $250 \mathrm{ml}$ flasks (100 ml medium) fitted with side-arms, were 16,32 and $136 \mathrm{~h}$ in SA broth, PA broth and SA broth containing $225 \mathrm{~mm}-\mathrm{Na}^{+}$, respectively. This confirmed a previous observation by Patel \& Roth (1977) that high $\mathrm{NaCl}$ concentrations inhibited growth and methane production of $M$. hungatii GP1. The final amount of growth attained after $7 \mathrm{~d}$ incubation was comparable in SA and PA broth, but in the presence of $225 \mathrm{mM}-\mathrm{NaCl}$ the final growth was decreased to one-third. Filament lengths (see Table 1 for SA and PA broth) increased significantly as the growth rate decreased. In the medium containing $225 \mathrm{~mm}-\mathrm{NaCl}$, the mean filament length was $277 \mu \mathrm{m}$ (not shown).

The possibility that high $\mathrm{PO}_{4}{ }^{3-}$ and high $\mathrm{NaCl}$ concentrations directly affected cell separation events was excluded by measuring filament lengths and growth rates of $M$. hungatii after cultivation in SA broth at $35^{\circ} \mathrm{C}$ and $25^{\circ} \mathrm{C}$. At the sub-optimal temperature of $25^{\circ} \mathrm{C}$ the biomass doubling time was $45 \mathrm{~h}$, measured in the exponential phase after a $260 \mathrm{~h}$ lag period, compared with about $20 \mathrm{~h}$ at $35^{\circ} \mathrm{C}$. This decrease in growth temperature also led to an increase in the mean filament length from $16 \mu \mathrm{m}$ at $35^{\circ} \mathrm{C}$ to $82 \pm 10 \mu \mathrm{m}$ at $25^{\circ} \mathrm{C}$.

Long filaments (from PA broth) re-inoculated into SA broth $\left[\mathrm{H}_{2} / \mathrm{CO}_{2}(4: 1, \mathrm{v} / \mathrm{v})\right]$ grew as short filaments. However, resuspension of long filaments in SA broth under conditions that did not support growth $\left[\mathrm{N}_{2} / \mathrm{CO}_{2}(4: 1, \mathrm{v} / \mathrm{v})\right]$ did not lead to the formation of short filaments. The effect of high $\mathrm{PO}_{4}{ }^{3-}$ concentrations on filament length is therefore not due to an inhibition in the activity of cell separation factors.

Since the cell spacers were about one cell length apart (Fig. 1), growth as long filaments was probably not caused by a failure in cross-wall formation, as reported for some rodshaped bacteria (Ferroni \& Inniss, 1974; Gounot, 1976). To investigate whether the reduced growth rates might correlate with a decreased synthesis of factor(s) responsible for cell separation, cells were grown in PA broth in the presence of extracts prepared from both short and long filaments (Table 1). The mean filament lengths of cells grown in PA broth (control) or in PA broth in the presence of a short-filament extract were significantly different $(P<0.01)$. Further, the filament lengths were related to the amount of extract added. A similar significance $(P<0.01)$ was noted between the means of samples which received heated and unheated short-filament extract $\left(200 \mu \mathrm{g}\right.$ protein $\left.\mathrm{ml}^{-1}\right)$. In contrast, growth in 
the presence of extract prepared from long filaments, or from culture supernatant, resulted in mean filament lengths that did not differ significantly from the control culture (PA broth). Since a decrease in length occurred in the presence of $44 \mathrm{mM}-\mathrm{PO}_{4}{ }^{3-}$, this provides further evidence that growth as long filaments in PA broth is not due to $\mathrm{PO}_{4}{ }^{3-}$ acting as an inhibitor of cell separation factors. It seems probable that at decreased growth rates the synthesis of a heat-labile component present in short-filament extracts is also decreased.

From these results, the possibility cannot be ruled out that the active extract causes an increased susceptibility of the cell wall to enzymic attack. Treatment with lysozyme, however, did not result in unchaining or cell lysis in long or short filaments of $M$. hungatii, even after pretreatment with $\beta$-glucuronidase from Helix pomatia, protease, trypsin, phospholipase A and C, or with EDTA. Further, penicillin G at $1000 \mu \mathrm{g} \mathrm{ml}^{-1}$ had little or no effect on cell growth and methane formation. These findings corroborate the recent report by Kandler \& König (1978) that the outer wall (or sheath) of $M$. hungatii lacks peptidoglycan.

Preliminary tests with another strain of $M$. hungatii (type strain JF1) indicated that it, too, can be selectively induced to grow as long filaments by incubation in high $\mathrm{PO}_{4}{ }^{3-}$ medium. High $\mathrm{PO}_{4}{ }^{3-}$ and $\mathrm{Na}^{+}$concentrations that caused filament formation in $M$. hungatii GP1 had no noticeable effect on the morphologies of three other methanogenic cultures tested; namely, Methanobacterium thermoautotrophicum, Methanobacterium strain M.O.H. and a strain similar to Methanobacterium formicicum.

\section{CONCLUSIONS}

Growth as long filaments is expected to have ecological significance. Filamentation should decrease the dispersal of the organism into the surrounding environment, both by decreasing the number of cell filaments and decreasing motility. The results also have significance in taxonomic and isolation work where predominant morphological types observed in natural ecosystems are seldom seen during laboratory cultivation in synthetic media. In part, this may be attributed to variations between the growth rates of the micro-organisms in their natural environment and those in laboratory media.

The authors appreciate the assistance of Dr J. R. Colvin and Mr L. C. Sowden with electron microscopy, and $\mathrm{Mr} \mathrm{R}$. H. Whitehead for taking photomicrographs. Technical assistance of $\mathrm{Mr} \mathrm{B}$. Agnew and Kathleen Shaw is also acknowledged. This paper is N.R.C.C. no. 17369.

\section{REFERENCES}

Colvin, J. R. \& Leppard, G. G. (1977). The biosynthesis of cellulose by Acetobacter xylinum and Acetobacter acetigens. Canadian Journal of Microbiology 23, 701-709.

FerRon, G. D. \& InNiss, W. E. (1974). Reversal of filament formation in the psychrophile Bacillus insolitus. Canadian Journal of Microbiology 20, 1281-1283.

FerRy, J. G., Smith, P. H. \& Wolfe, R. S. (1974). Methanospirillum, a new genus of methanogenic bacteria, and characterization of Methanospirillum hungatii sp.nov. International Journal of Systematic Bacteriology 24, 465-469.

Gounot, A. M. (1976). Effects of temperature on the growth of psychrophilic bacteria from glaciers. Canadian Journal of Microbiology 22, 839-846.

KANDLER, O. \& KöNIG, H. (1978). Chemical composition of the peptidoglycan-free cell walls of methanogenic bacteria. Archives of Microbiology 118, 141-152.
Lominski, I., Cameron, J. \& Wyllie, G. (1958). Chaining and unchaining Streptococcus faecalis a hypothesis of the mechanism of bacterial cell separation. Nature, London 181, 1477.

LoWry, O. H., Rosebrough, N. J., FARR, A. L. \& RANDALL, R. J. (1951). Protein measurement with the Folin phenol reagent. Journal of Biological Chemistry 193, 265-275.

Mylroie, R. L. \& Hungate, R. E. (1954). Experiments on the methane bacteria in sludge. Canadian Journal of Microbiology 1, 55-64.

PAtel, G. B. \& Roth, L. A. (1977). Effect of sodium chloride on growth and methane production of methanogens. Canadian Journal of Microbiology 23, 893-897.

Patel, G. B., Roth, L. A., VAN den Berg, L. \& CLARK, D. S. (1976). Characterization of a strain of Methanospirillum hungatii. Canadian Journal of Microbiology 22, 1404-1410.

Robinow, C. F. \& Murray, R. G. E. (1953). The 
differentiation of cell wall, cytoplasmic membrane and cytoplasm of Gram-positive bacteria by selective staining. Experimental Cell Research 4, 390-407.

Smith, P. H. \& Hungate, R. E. (1958). Isolation and characterization of Methanobacterium ruminantium n.sp. Journal of Bacteriology 75, 713-718.

WebB, M. (1951). The influence of magnesium on cell division. 6 . The action of certain hydrolytic enzymes on the filamentous and chain forms of Gram-positive rod-shaped organisms. Journal of General Microbiology 5, 496-501.

ZEHNDER, A. J. B. \& WUHRMANN, K. (1977).
Physiology of a Methanobacterium strain AZ. Archives of Microbiology 111, 199-205.

ZeIKus, J. G. \& BowEN, V. G. (1975). Fine structure of Methanospirillum hungatii. Journal of Bacteriology 121, 373-380.

Zeikus, J. G. \& Henning, D. L. (1975). Methanobacterium arbophilicum sp.nov. An obligate anaerobe isolated from wetwood of living trees. Antonie van Leeuwenhoek 41, 543-552.

ZeIKUS, J. G. \& Wolfe, R. S. (1973). Fine structure of Methanobacterium thermoautotrophicum: effect of growth temperature on morphology and ultrastructure. Journal of Bacteriology 113, 461-467. 